\title{
OS CONTRATOS EMPRESARIAIS E A POSSIBILIDADE DE ERRO ENQUANTO VÍCIO DE CONSENTIMENTO
}

\author{
Raul Durizzo de Oliveira
}

Pontifícia Universidade Católica do Paraná - PUCPR, Curitiba, PR. E-mail: rauldurizzo@gmail.com

\section{RESUMO}

O presente trabalho procura expor, por meio de análise bibliográfica, doutrinária e legislativa, os conceitos de negócio jurídico e de vícios de consentimento, notadamente o erro, e dissecar o contrato empresarial, conceituando-o e apontando os critérios interpretativos a ele aplicáveis, com o fito de examinar se é possível que manifestações de vontade nos pactos mercantis sejam eivadas de erro, levando à anulação do negócio. Dessa forma, procura-se caracterizar o empresário enquanto tomador de decisões à frente da empresa e elencar quais vetores devem ser utilizados para se entender uma relação empresarial. Considerando que o contrato empresarial essencialmente busca o lucro e, por isso, está envolto de risco, bem como que o empresário que o firma não é qualquer indivíduo, mas pessoa presumidamente qualificada, o erro não é subterfúgio para se requerer a anulação do negócio.

Palavras-chave: Vícios de consentimento. Erro. Contratos empresariais. Empresa. Empresário.

\section{THE BUSINESS CONTRACTS AND THE POSSIBILITY OF ERROR AS A CONSENT VICE}

\begin{abstract}
The present work seeks to expose, by means of bibliographic, doctrinal and legislative analysis, the concepts of legal business and consent defects, notably the error, and dissect the business contract, conceptualizing it and pointing out the interpretive criteria applicable to it, with the purpose of examining whether it is possible that manifestations of will in the commercial pacts are riddled with error, leading to the annulment of the business. Thus, it seeks to characterize the entrepreneur as a decision maker at the head of the company and to list which vectors should be used to understand a business relationship. Considering that the business contract essentially seeks profit and, therefore, is involved in risk, as well as that the entrepreneur who signs it is not any individual, but a presumably qualified person, the error is not a subterfuge to request the annulment of the bargain.
\end{abstract}

Keywords: Consent vices. Error. Business contracts. Company. Businessman.

\section{INTRODUÇÃO}

Com a promulgação do Código Civil de 2002 boa parte do Direito Empresarial passou a ser regulamentado pela lei civil, que dispõe de capítulo próprio para tratar dos assuntos relativos à empresa.

Da mesma forma, a regulação das interações empresariais é feita com base nos dispositivos constantes no aludido código, mormente pelas cláusulas gerais da boa-fé objetiva e função social do contrato.
Ocorre, todavia, que o Direito Empresarial, muito embora integrante do campo maior do Direito Privado e, por isso, descendente de um tronco comum, distancia-se muito do Direito Civil em muitas questões. Nessa senda, é óbvio que os negócios celebrados entre empresas estão envoltos em circunstâncias completamente diversas dos pactuados por indivíduos comuns no dia a dia.

Posto isso, por mais que a empresa celebre negócios jurídicos e contratos diariamente, faz-se necessário avaliar se as regras aplicáveis a tais 
institutos de Direito Civil são integralmente utilizadas como parâmetro para interpretação dos negócios empresariais.

Busca-se com a presente pesquisa, portanto, analisar se é possível aplicar aos contratos empresariais a norma civil que prevê a anulabilidade do negócio mediante o erro, vício de consentimento que torna defeituosa a vontade manifestada.

\section{METODOLOGIA}

Este trabalho é estruturado a partir de uma abordagem qualitativa, tendo como instrumento de coleta de dados e informações para sua confecção a pesquisa bibliográfica, que foi realizada através de livros, artigos científicos, revistas especializadas e sites jurídicos.

\section{O NEGÓCIO JURÍDICO E OS VÍcIOS DE CONSENTIMENTO NEGÓCIO JURÍDICO E AUTONOMIA PRIVADA}

Segundo a lição de Junqueira de Azevedo (2002, p. 16), os negócios jurídicos estruturalmente podem ser definidos como categoria, isto é, como fato jurídico abstrato, ou como fato, ou seja, como ato jurídico concreto.

Como categoria, é a hipótese de fato que, dotado de força jurígena, consiste em "manifestação de vontade cercada de certas circunstâncias (as circunstâncias negociais) que fazem com que socialmente essa manifestação seja vista como dirigida à produção de efeitos jurídicos" (ibidem, loc. cit.). Concretamente, o negócio jurídico nada mais é senão "declaração de vontade, a que o ordenamento jurídico atribui os efeitos designados como queridos, respeitados os pressupostos de existência, validade e eficácia impostos pela norma" (ibidem, loc. cit.).

Assim sendo, negócio jurídico é a hipótese de fato jurídico, unilateral, bilateral ou plurilateral, que se caracteriza pela manifestação social de vontade do indivíduo, a vontade negocial, direcionada a alcançar um efeito jurídico desejado. A vontade dirigida, ou seja, a manifestação de querer um algo específico é, portanto, a essência do negócio jurídico.

Aludida possibilidade de o indivíduo agir de acordo com a sua vontade é a mais pura manifestação de liberdade jurídica e encontra guarida no princípio da autonomia privada. Na lição de Francisco do Amaral (2018, P, 131) "autonomia privada é o poder que os particulares têm de regular, pelo exercício de sua própria vontade, as relações de que participam, estabelecendo-lhes o conteúdo e a respectiva disciplina jurídica".
Para ele (ibidem, loc. cit.), ela se forma a partir do reconhecimento de um âmbito particular de atuação da pessoa, com eficácia normativa. É, dessa forma, a concessão pelo Estado de uma esfera de atuação aos particulares que, muito embora limitada por normas de ordem pública cogentes e imperativas, permite-lhes conferir eficácia jurídica a atos variados, criando, modificando ou extinguindo situações jurídicas.

Nesse sentido, é o negócio jurídico in concreto a materialização do princípio da autonomia privada, uma vez que é "o meio prático posto à disposição dos particulares [...] para exercício dessa autonomia" (MIRANDA, 2009, p. 44).

Justamente por isso, censuráveis são as "declarações decorrentes de vontades débeis, ou não correspondentes à exata consciência da realidade, ou provenientes de violência imposta sobre a pessoa que a emitiu" (AZEVEDO, 2002, p. 42), sob pena do negócio jurídico esvair-se em sua própria essência. Nesse caso, caso chegue a ser entabulado, poderá o negócio ser anulado a requerimento da parte interessada, conforme preceitua o art. 171, II, do Código Civil.

\section{VÍCIOS DE CONSENTIMENTO}

Para que o negócio seja válido e produza efeitos mister que a manifestação de vontade seja “a) resultante de um processo volitivo; b) querida com plena consciência da realidade; b) escolhida com liberdade; d) deliberada sem má-fé" (ibidem, p. 43).

Quando o indivíduo se utiliza de patente máfé, isto é, quando a externalização de vontade do agente corresponde com a sua vontade íntima, porém essa atenta contra a lei vigente, tem-se um vício que acarreta na invalidade do negócio denominado vício social. Nesses casos, como ressalta Caio Mário da Silva Pereira (2020a, p. 435), muito embora haja um negócio jurídico e exista uma declaração de vontade, esta última, por fatores endógenos, traduz uma volição que visa a resultados condenados ou condenáveis.

Por outro lado, quando a vontade do indivíduo é manifestada em desacordo com o seu querer original e íntimo, ou seja, a sua real vontade, torna-se defeituoso - e anulável - o ato em razão de um vício de consentimento. São denominados vícios de consentimento (ou de vontade) uma vez que ocorrem por "influências exógenas sobre a vontade exteriorizada ou declarada, e aquilo que é ou devia ser a vontade real, se não tivessem intervindo as circunstâncias que sobre ela atuaram, provocando a distorção" (ibidem, loc. cit.). 
Averígua-se, em tais casos, que a exteriorização de vontade não foi resultante de um processo volitivo ou querida com plena consciência da realidade, tampouco escolhida com liberdade.

Tradicionalmente, reconhece-se como vícios de consentimento o erro, o dolo e a coação, previstos nos artigos 138 a 144, 145 a 150 e 151 a 155 do Código Civil, respectivamente.

A coação é a injusta ameaça empregada em face do indivíduo, de sua família ou de seus bens com o intuito de força-lo a praticar determinado ato jurídico. Conforme elucida Francisco Amaral (2018, P. 603), não é a coação, isto é, a ação coatora propriamente dita, o vício da vontade em si, mas sim o temor que ela inspira e que torna defeituosa a manifestação de querer do agente.

Pode ser relativa, quando a violência utilizada possui caráter psicológico, oportunidade em que o indivíduo manifesta sua vontade de maneira viciada, isto é, há declaração de vontade do agente, ainda que defeituosa. Por outro lado, pode ser absoluta, ocasião em que o indivíduo se encontra sob violência física, externalizando não a sua própria vontade, mas sim a do agente coercivo. Considerando as particularidades de ambas as modalidades de coação o negócio é anulável no primeiro caso, e, no segundo, inexistente, haja vista que não houve declaração de vontade.

Tendo em vista que "a coação vem a ser o vício mais profundo que pode afetar o negócio jurídico, uma vez que seu impacto o atinge na própria base, na vontade livre do agente" (MALUF, 2018, p. 446), abre-se pouco espaço para discussão no que tange à necessidade de anulação ou, minimamente, revisão dos negócios entabulados sob seus efeitos.

Adiante, tem-se o dolo que, genericamente, é concebido como qualquer "artifício empregado para enganar alguém (dolus est consilium alteri nocendi) e induzi-lo à prática de um ato que o prejudica ou a terceiros" (ibidem, p. 435). Trata-se do meio ardil utilizado por outrem, de forma omissiva ou comissiva, com o intuito de induzir ou manter em erro o autor da manifestação de vontade, em benefício próprio ou de terceira pessoa.

Para que seja considerado vício de consentimento e enseje a anulabilidade do negócio jurídico, é fundamental que se trate do "dolus malus caracterizado pela perversidade de propósito, e não [d]o dolus bonus ou inocente, que consiste em adulações e blandícias no apregoamento publicitário de qualidades" (PEREIRA, 2020a, p. 445).

Ainda, nas palavras de Orlando Gomes (2019a, p. 302), o dolo pressupõe fundamentalmente dois elementos: um objetivo e outro subjetivo. O primeiro é o comportamento ilícito de quem quer enganar a outra parte e o segundo, a intenção de enganar (animus decipiendi).

Vê-se, portanto, que o desacordo entre a vontade original do indivíduo e aquela que foi manifestada ocorre por deliberada má-fé de outrem, ocasionando evidente lesão à parte. Por isso, tal qual ocorre no caso de coação, pouco se questiona a respeito da necessidade de anulação ou, em certos casos, até mesmo reparação civil, de negócios entabulados determinantemente em razão de dolo.

Quando se fala em erro, contudo, a manifestação de vontade é expressada de forma defeituosa por circunstâncias que partem do próprio indivíduo, e não de um terceiro.

Erro é a falsa percepção da realidade que envolve o negócio, é um estado de equívoco do agente relativo aos elementos negociais, seja quanto ao objeto, seja quanto à pessoa. Conforme explica Caio Mário da Silva Pereira (2020a, p. 438), o indivíduo incorre em erro quando age mediante o desconhecimento ou o falso conhecimento das circunstâncias fáticas, de um modo que não seria a sua vontade caso se conhecesse a verdadeira situação.

A lei trata de forma indistinta tanto o erro quanto a ignorância, que seria o desconhecimento completo a respeito da realidade do negócio, haja vista que as suas interferências na vontade são as mesmas.

O erro, para que seja causa de anulação do negócio, deve ser essencial, ou seja, incidir sobre fato ou circunstância determinante à formação do negócio, sem a qual o indivíduo não manifestaria a sua vontade. Isso quer dizer que é necessário que "recaia na substância do ato, no objeto principal da declaração ou em alguma das suas qualidades substanciais, ou que diga respeito a qualidades essenciais da pessoa a quem se refira a declaração de vontade" (GOMES,2019a, p. 300).

A partir disso a doutrina tradicionalmente classifica as principais modalidades de erro essencial da seguinte maneira: o error in negotio, que recai sobre a natureza do ato; error in corpore, que falseia a realidade da identidade ou das qualidades da coisa; error in persona, que incide na identidade e nas qualidades do destinatário da manifestação de vontade e; error in quantitate, quando o erro em relação à quantidade das coisas é o motivo determinante da vontade do agente.

Imprescindível, outrossim, que o erro seja escusável, isto é, não seja grosseiro ou de fácil constatação, que com certa diligência por parte de 
um indivíduo comum poderia ser evitado. É aquele erro "justificável, desculpável, posto que qualquer pessoa comum, em idêntica situação, poderia nele incidir" (MALUF, 2018, p. 425).

Muito embora aludido requisito não esteja expressamente disposto nos artigos que tratam do erro no Código Civil, entende-se que está subentendido na norma haja vista que implícito como elemento do próprio conceito de erro. Acrescenta Miranda (2009, p. 202) que não é digno de proteção o interesse do errante em caso de erro inescusável quando em confronto com o interesse do receptor da declaração de vontade, haja vista que esse último experimentaria injusta quebra de expectativa em caso de anulação do negócio.

Cita-se, ainda, que no que tange à escusabilidade do erro, privilegiou-se a interpretação que leva em conta as circunstâncias negociais, e não o agente em si, uma vez que "o novo diploma adotou um padrão abstrato do homem médio (homo medius)"(MALUF, 2018, p. 425).

Modernamente, contudo, tem-se acrescido o requisito da reconhecibilidade, ou cognoscibilidade, a partir de uma interpretação mais abrangente do art. 138 do Código Civil, que assevera que os negócios serão anuláveis "quando as declarações de vontade emanarem de erro substancial que poderia ser percebido por pessoa de diligência normal" (BRASIL, 2002). Nessa esteira, com base na teoria da confiança, a pessoa de diligência normal referida no Código que deveria perceber o erro não é o declarante, mas o destinatário da declaração (PEREIRA, 2020a, p. 442).

Verificar-se-ia o requisito citado a partir de duas possibilidades, conforme explica Miranda (2009, p. 201): "quando o destinatário da declaração conhecia a verdadeira situação, isto é, tinha efetivo conhecimento da existência do erro ou quando, embora desconhecendo essa situação, poderia conhece-la com o uso de diligência normal". No primeiro caso, estaria delineada má-fé do receptor da manifestação de vontade, no segundo, entretanto, apenas culpa em sentido lato.

Distingue-se, também, nos termos do magistério de Francisco Amaral (2018, p. 596), o erro de fato, que incide nas circunstâncias ou elementos do negócio (acima arrolados), do erro de direito, que é o falso conhecimento ou ignorância da regra jurídica pertinente ao caso. Importante esclarecer, entretanto, que o erro de direito só torna o negócio anulável se a manifestação de vontade teve como fator determinante a ignorância da norma, isto é, quando o declarante não a manifestaria caso tivesse ciência do que pressupõe o texto legal.

De todo modo, vê-se que no erro a declaração de vontade não é manifestada de forma defeituosa por conduta de terceiros, ou seja, o vício de vontade não é provocado. Na realidade, é o próprio indivíduo, cuja consciência está encoberta por uma falsa percepção da realidade, que conduz ao desacordo entre a sua vontade íntima e a externalizada.

Mesmo que se admita, como se tem feito, o requisito da cognoscibilidade e a hipótese de o receptor da declaração de vontade ter ciência de que o indivíduo age em erro, o que denotaria má-fé, ainda assim não houve interferência no processo de formação da vontade.

Posto isso, a aferição do vício se volta não para determinado fato que tenha deturpado a vontade original, mas para $o$ indivíduo que a manifestou, em cotejo com as circunstâncias negociais, levando-se em consideração, ainda, o padrão do homem médio.

\section{CONTRATOS E CONTRATOS EMPRESARIAIS O CONTRATO E A AUTONOMIA CONTRATUAL}

Dito isso, sabe-se que a doutrina do negócio jurídico está intimamente ligada ao direito contratual. O Contrato é, conforme será melhor elucidado, negócio jurídico e pressupõe a manifestação de vontade das partes. Assim sendo, eventuais defeitos de consentimento dos contratantes podem ensejar a anulação de um contrato.

Dentro do vasto campo da autonomia privada, encontra-se a liberdade de contratar. A liberdade contratual, ou autonomia contratual, é o poder conferido pelo ordenamento jurídico às partes de estipular o conteúdo do contrato, isto é, "de estabelecer qual é o resultado que através de um determinado contrato as partes queiram realizar e quais regras de comportamento as partes deverão seguir e a quais resultados" (CABRAL, 2004).

Assim sendo, tal qual a liberdade de contratar é a espécie da qual a autonomia privada é gênero, o contrato, enquanto materialização da liberdade contratual, é espécie da qual o negócio jurídico, que concebe a autonomia negocial de forma ampla dentro da autonomia privada, é o gênero.

Em uma, nesse tocante, o contrato é um negócio jurídico que pressupõe a bilateralidade, ou multilateralidade, e, por conseguinte, o consentimento de todos os envolvidos com a finalidade de produzir efeitos jurídicos. Com isso, são 
aplicáveis aos contratos todas as disposições que regulamentam os negócios jurídicos, mormente no que diz respeito aos vícios de vontade.

De forma autônoma, o conceito de contrato é pacífico na doutrina, sendo pertinente destacar as palavras de Caio Mário da Silva Pereira que o define como "um acordo de vontades, na conformidade da lei, e com a finalidade de adquirir, resguardar, transferir, conservar, modificar ou extinguir direitos" (PEREIRA, 2020b, p. 6).

Característica peculiar e essencial aos contratos é, conforme assevera Orlando Gomes (2019b, p. 16), o seu conteúdo econômico: a vida econômica é instrumentalizada pela imensa rede dos contratos que a ordem jurídica oferece aos sujeitos de direito para que regulem com segurança seus interesses. Assim, todo contrato tem uma função econômica, que é, afinal, a sua causa de existir.

Ainda segundo magistério de Gomes (2019b, loc. cit.), aludida função econômica é manifesta em uma gama de situações, havendo contratos: para promover a circulação de riqueza; de colaboração; para prevenção de risco; de conservação e acautelatórios; para prevenir ou dirimir uma controvérsia; para a concessão de crédito; constitutivos de direitos reais de gozo, ou de garantia.

O processo de formação do contrato, superadas eventuais tratativas pré-contratuais, pressupõe duas etapas: a proposta, também chamada de oblato, e o aceite.

Em primeiro lugar, uma das partes integrantes da relação envia à outra a proposta, que nada mais é do que uma "declaração unilateral receptícia, que se distingue por já conter todos os elementos essenciais à formação do contrato" (KONDER; TEPEDINO, 2020, p. 87).

Nesse sentido, a proposta carrega consigo a oferta de formação do contrato em si que, passando-se à segunda etapa, é perfectibilizado e nasce com o aceite. Antes da aceitação, "inexiste ainda contrato, cujo pressuposto é o consentimento. Somente quando o oblato se converte em aceitante, e faz aderir a sua vontade à do proponente, a oferta se transforma em contrato" (PEREIRA, 2020b, p. 40).

É justamente nesse processo que reside a manifestação de vontade das partes como instrumento de sua liberdade contratual e, consequentemente, de sua autonomia privada. Caso um dos contratantes, portanto, perfectibilize o contrato sob influência de uma vontade viciada, caberá anulação do negócio.

\section{CONTRATOS EMPRESARIAIS}

No que tange aos contratos empresariais, há que se destacar que, muito embora a teoria geral dos contratos seja, por óbvio, aplicada aos pactos desta espécie, as suas particularidades demandam a formulação de uma matéria própria em virtude de estarem inseridos no ambiente específico da exploração de atividade econômica (RIBEIRO, 2018). Nesse sentido, diferentemente dos sujeitos comuns contemplados pela legislação civil, aquele que exerce a atividade econômica estará sujeito especificamente à disciplina da empresa (GALESKI JUNIOR; RIBEIRO, 2015, p. 25).

O Direito Empresarial, à míngua de manifestação expressa na lei positivada, desenvolve o conceito de empresa a partir da concepção econômica do termo, "ligada à ideia central da organização dos fatores da produção (capital, trabalho, natureza), para a realização de uma atividade econômica" (TOMAZETTE, 2019, p. 63).

A partir disso, com grande influência da doutrina Italiana de Alberto Asquini, o jurista Waldirio Bulgarelli conceituou empresa como uma "atividade econômica organizada de produção e circulação de bens e serviços para o mercado, exercida pelo empresário, em caráter profissional, através de um complexo de bens" (BULGARELLI, 2000 , p. 100), complexo esse denominado de estabelecimento empresarial.

A empresa, assim sendo, não somente existe, mas também atua e interage no plano econômico das mais variadas formas possíveis para suprir suas demandas e cumprir com a finalidade para que se destina. "A empresa não vive ensimesmada, metida com seus ajustes internos; ela revela-se nas transações" (FORGIONI, 2019, p. 23). Relacionar-se e entabular negócios com outros agentes é o que dá vida e existência à atividade empresária.

Nesse contesto, a empresa firma pactos com os mais diversos entes, tais como o Estado, particulares, empregados, consumidores etc. Nem todos eles, contudo, poderão ser considerados contratos empresariais e interessarão ao direito empresarial. Os contratos empresariais distinguemse dos demais contratos em razão de seus sujeitos, de sua história e sua função (GALESKI JUNIOR; RIBEIRO, 2015, p. 32-33).

Quanto ao elemento histórico, é cediço que, no decorrer dos anos, "os negócios empresariais [passaram a possuir] uma força jurígena com muito mais intensidade nos usos e costumes do que nos arcabouços normativos dos Códigos" (CARNEIRO FILHO; VIANA, 2015). Assim sendo, assevera Ribeiro 
(2018), adquiram características de informalidade e atipicidade, as quais decorrem da dinamicidade da atividade empresarial, conduzindo o empresário à criação e ao aperfeiçoamento de modelos contratuais que atendam e adaptam-se às suas necessidades negociais.

Posto isso, nem todas as normas aplicáveis aos contratos comuns terão efeitos sobre os pactos empresariais, sob pena de engessá-los em um sistema incompatível com a sua natureza. Ademais, a interpretação dos contratos entre empresas seguirá um norte diverso da que usualmente se utiliza para dirimir conflitos em contratos comuns, privilegiando-se os princípios atinentes ao direito empresarial.

A sua função é muito bem delineada e justifica a própria necessidade de as empresas entabularem acordos e transações: proporcionar a circulação de riquezas, indispensável à prática empresarial. Elucidam Galeski Junior e Ribeiro (2015, p. 33) que a função imediata dos contratos mercantis está associada aos negócios ali disciplinados, à pactuação dos interesses envolvidos nos contratos, com o fito de promover o desenvolvimento eficaz da atividade empresarial.

No que tange aos sujeitos, são eles invariavelmente empresários que, no momento de formação do contrato, o fazem no exercício de suas atividades profissionais. Dessa forma, "identificamos os contratos empresariais com aqueles em que ambos [ou todos] os polos da relação têm sua atividade movida pela busca do lucro" (FORGIONI, 2019, p. 27-28).

Diante disso, observa-se que a principal característica dos contratos empresariais é a busca do lucro. Eles são fruto da necessidade empresarial, sendo que, por meio dele, as empresas manifestam o seu único objetivo, que é a obtenção de vantagem econômica.

Assevera Paula Forgioni (2019, p. 109) que, se toda movimentação empresarial no mercado tem o condão de auferir lucro, supõe-se que a celebração dos contratos interempresariais invariavelmente se dá porque todas as partes acreditam que seus interesses estão sendo satisfeitos.

Justamente por possuir tal característica, os contratos empresariais são sempre envoltos de riscos, os quais são inerentes à atividade empresária.

Aquele que busca empreender está de antemão ciente dos riscos que assume com sua atividade econômica. "A prosperidade ou o fracasso da empresa estão sempre sujeitos a determinada margem aleatória; não dependem de fatores inteiramente controláveis e antecipáveis pelo empresário" (COELHO, 2014, p. 97). Trata-se, tal conceito, do princípio da inerência do risco.

Dessa forma, o empresário é sabedor de que os pactos firmados no âmbito empresarial podem, por uma série de fatores econômicos e de mercado, causar-lhe prejuízo ou, no mínimo, resultados não queridos. Ainda assim o contrato empresarial não perderá sua essência, que é o escopo de lucro. "Isto é, o contrato pode ser de lucro, embora tenha efetivamente causado prejuízo à parte" (AGUIAR JÚNIOR, 2011).

Por essa razão, nos pactos interempresariais, ensina Aguiar Júnior (2011), a intervenção heterônoma, leia-se, do judiciário, seria de menor força haja vista que se cuida de atividade de risco, cujo objetivo é o lucro, com propósito eminentemente patrimonial, cabendo às partes a assunção dos prejuízos inerentes à atividade.

Finalmente, há que se destacar que as partes envolvidas em um contrato empresarial são presumidamente paritárias e equânimes em todos os aspectos: técnico, informacional, econômico e jurídico.

Isso porque a atividade empresária pressupõe o profissionalismo, ou seja, o conhecimento particular e aprofundado não só de seu ramo de atuação, mas de todos os elementos que envolvem a realidade do mercado. "Parte-se da presunção de que as partes são dotadas de conhecimentos específicos, que lhes dão condições de negociar as cláusulas do contrato de acordo com os seus interesses" (DEZEM; OLIVEIRA FILHO, 2019).

Além de presumidamente profissionais, apresentam condições similares de acesso à informação e análise dos riscos que permeiam toda a negociação empresarial, justamente por ambos serem empresários (GALESKI JUNIOR; RIBEIRO, 2015, p. 33).

Com isso, haverá quebra na paridade mencionada somente em situações excepcionalíssimas e, ainda assim, a interferência exógena no sentido de buscar o reequilíbrio da relação é exceção e medida ultima ratio.

\section{O EMPRESÁRIO E A TOMADA DE DECISÕES}

Como visto, os contratos empresariais possuem tal predicado porque pactuados fundamentalmente por empresários no exercício de suas atividades empresariais em ambos, ou todos, os polos.

Seja o empresário pessoa física, como empresário individual, ou pessoa jurídica, como sociedade empresária de qualquer natureza, é ele quem detém o "poder de iniciativa e de decisão, pois 
cabe-lhe determinar o destino da empresa e o ritmo de sua atividade, assumindo todos os riscos, ou seja, as vantagens ou prejuízos" (DINIZ, 2012, p. 57). O que diferirá é que no caso de sociedades empresárias o controle e direção ficarão a cargos do sócio administrador ou de diretor nomeado pela sociedade.

De uma forma ou de outra, espera-se que o empresário seja detentor de alguns requisitos imprescindíveis ao exercício da atividade empresária.

O primeiro e mais notável é o da diligência. Modesto Carvalhosa (2013, p. 379), ao lecionar a respeito dos predicados requeridos de um administrador de sociedades anônimas, explica que "o dever de diligência expressa-se normativamente pela figura do administrador ativo e probo, que deve dispensar aos negócios societários o mesmo cuidado que dispensaria na condução de seus próprios interesses".

Isso quer dizer que o indivíduo que detém o poder de controle da empresa deve agir de forma prudente, sensata e proba, tal qual faria com os seus próprios negócios.

Outrossim, entende-se no âmbito jurídico que diligência "é o adequado emprego de energias e meios úteis para realização de um fim determinado" (HENTZ; SOBONGI, 2016). Dessa forma, vê-se que o dever de diligência não pressupõe somente cautela, mas também perspicácia e sagacidade por parte do empresário no trato dos elementos que evolvem a atividade empresarial para que, a partir disso, ela alcance o seu objeto social.

Nesse sentido, o Código Civil em seu art. 1.011, ao dispor a respeito da administração das sociedades empresárias, assevera que "o administrador [...] deverá ter, no exercício de suas funções, o cuidado e a diligência que todo homem ativo e probo costuma empregar na administração de seus próprios negócios" (BRASIL, 2002). Na mesma linha, o art. 153 da Lei das Sociedades Anônimas, em capítulo próprio que trata dos deveres e responsabilidades do administrador da S/A, afirma que "o administrador da companhia deve empregar, no exercício de suas funções, o cuidado e diligência que todo homem ativo e probo costuma empregar na administração dos seus próprios negócios" (BRASIL, 1976).

Em suma, conforme pontua Chiavenato (2020, p.3), do administrador precisa saber "analisar e avaliar cada situação com clareza, obter dados e informação suficientes para julgar os fatos com espírito crítico, ponderar com equilíbrio, definir prioridades e tomar decisões".
Ademais, espera-se que do empresário conhecimento técnico, não somente da sua área de atuação, mas também de como gerir o seu negócio. Carvalhosa (2013, p. 368) lembra que são insuficientes ao empresário a diligência e honestidade, sendo-lhe necessário dispor de competência profissional específica, traduzida por escolaridade ou experiência e, se possível, ambas (CARVALHOSA, 2013, p. 368).

Fundamental, portanto, que o empresário tenha, no mínimo, conceitos claros a respeito da ciência da administração de empresas e saiba colocá-los em prática. Em poucas palavras, o mote da administração é o de:

interpretar os objetivos
propostos pela organização e
transformá-los em ação
organizacional por meio do
planejamento, organização,
direção e controle de todos os
esforços realizados em todas
as áreas e em todos os níveis
da organização, a fim de
alcançar tais objetivos da
maneira mais adequada à
situação e garantir a
competitividade em um
mundo de negócios altamente
concorrencial e complexo
(CHIAVENATO, 2020, p. 10).

Destaca-se, nesse sentido, que a administração propõe a ação organizacional e planejada como meio de se alcançar os objetivos empresariais da maneira mais adequada à realidade em que a empresa se insere, garantindo a sua posição de mercado.

Dessa forma, espera-se do empresário que todas as suas ações a frente da empresa estejam calcadas em um planejamento prévio, mormente no que tange à alocação de riscos, e que integrem uma cadeia de atos que tem por finalidade máxima a vantagem econômica.

Por essas razões, o empresário, no exercício de suas funções, assume posição tal que trespassa a condição de um indivíduo comum. Em decorrência das responsabilidades que assume, dos riscos que atrai para si, bem como dos predicados que, supõese, ostenta, a interpretação de seus atos deve ser mais criteriosa, levando-se em conta todos os elementos já citados.

Além do mais, a análise da ação do empresário "deve ter como critério a comparação com a conduta de outros administradores, em negócios semelhantes e submetidos às mesmas 
circunstâncias temporais e de lugar" (CARVALHOSA, 2013 , p. 379). Assim, mede-se a sua manifestação de vontade na relação contratual em razão da realidade do mundo dos negócios, da sistemática do mercado, e não à luz da ordem que rege as relações entre indivíduos comuns.

\section{VETORES DE FUNCIONAMENTO DOS CONTRATOS EMPRESARIAIS}

As peculiaridades dos contratos empresariais, assim como dos agentes que o entabulam, conduzem à necessidade de identificação e análise de parâmetros comuns a todos os pactos mercantis, a fim de se compreender o peculiar funcionamento dessa categoria autônoma de negócios jurídicos e o seu desenvolvimento no mundo fático.

A partir disso, Paula A. Forgioni (2019, p. 107-177) estabeleceu, em suas palavras, alguns vetores de funcionamento que se manifestam como diretrizes interpretativas dos contratos empresariais. Ao estudo deste trabalho não é pertinente pormenorizar cada, motivo pelo qual far-se-á menção de alguns deles, apenas.

O primeiro e mais significativo, que dá conteúdo ao contrato empresarial, é o escopo de lucro. "O fim lucrativo é a característica fundamental a partir do qual se desdobram as demais peculiaridades dos negócios mercantis, sendo o contrato um instrumento para atingir esse fim maior" (ibidem, p. 109).

O empresário sequer cogita firmar um pacto sem pressupor que estará auferindo lucro. Qualquer negociação mercantil somente é levada a cabo a partir do momento em que todos os agentes envolvidos compreendem que o negócio a ser entabulado é proveitoso.

Tal questão se liga intimamente ao segundo vetor digno de nota: o norte dos contratos empresariais é a sua função econômica. Forgioni (2019, p. 117) elucida que as partes não contratam pelo mero prazer; ao se vincularem, as empresas têm em vista determinado escopo, que se funde à função que esperam que o negócio desempenhe. Assim sendo, todo negócio possui uma função econômica.

Nenhum contrato mercantil é firmado de forma alheia à lógica estrutural e do planejamento da empresa. Se o empresário externaliza a sua vontade de contratar é porque o resultado daquele negócio é esperado, querido e fundamental aos interesses da atividade econômica, promovendo a circulação de bens, serviços e riquezas.
Considerando que a busca por proveito econômico é a razão de existência da atividade empresarial, todos os contratos formalizados pela empresa possuem uma função econômica que, no fim, é auferir lucro (AGUIAR JÚNIOR, 2011).

Em decorrência disso, estabelece-se um outro vetor de funcionamento, que é egoísmo, ou oportunismo, do agente econômico.

Regra geral, excetuando-se os contratos de parceria, a empresa atua no mercado com vista a satisfazer exclusivamente as suas demandas particulares, isto é, perseguir o seu próprio lucro; o agente econômico é naturalmente egoísta.

No mercado, não há agentes ingênuos, altruístas e caridosos. As empresas precisam preservar suas atividades e obter lucro, o que mantém o empresário constantemente atento às oportunidades de utilizar em seu favor os elementos negociais que se apresentarem, mesmo que seja que em desfavor de outros (FORGIONI, 2019, p. 123).

Como isso, condiciona-se a interpretação dos pactos empresariais a mais um vetor, o dos custos de transação. Conforme explica Forgioni (2019, p. 145), o agente econômico escolhe sempre a alternativa que se apresenta como a melhor disponível, ponderando os custos que deverá cuja contratação irá gerar (custos de transação).

A empresa cotidianamente possui a necessidade de se suprir de bens e serviços relacionados à atividade econômica desempenhada, seja na aquisição de matérias primas, manutenção de equipamentos e prédios, subsídios tecnológicos etc.

Há, assim sendo, a possibilidade de tais demandas serem supridas pela própria empresa, ou pela contratação de uma terceira, o que geralmente ocorre na dinâmica empresarial.

De qualquer forma, toda ação da empresa nesse sentido busca minimizar os custos e potencializar os ganhos. Inexistirá contrato se os custos que o envolvem forem desinteressantes para a parte que necessita do bem ou serviço.

Ademais, conforme mencionado anteriormente, além da busca pelo lucro, o contrato empresarial tem por característica a presença do risco do negócio. Em verdade, qualquer negócio envolve riscos, contudo no esfera do mercado eles são ainda maiores.

Dessa forma, importante mencionar o vetor interpretativo que conduz à ideia de que o contrato funciona como instrumento de alocação de riscos. "O contrato é um instrumento de alocação, entre as partes, dos riscos da atividade econômica" 
(FORGIONI, 2019, p. 148), sejam eles previsíveis ou imprevisíveis.

Isso quer dizer que quando as partes entabulam um pacto de natureza empresarial já estão embutindo em suas cláusulas a divisão mútua dos riscos que envolvem a operação e de eventuais prejuízos dele decorrentes.

Isso porque é justamente o risco inerente ao negócio que legitima a apropriação dos lucros na atividade empresarial (RIBEIRO, 2018). Para haver lucro, é preciso que haja a assunção e divisão de riscos.

Assim, ao se interpretar um contrato empresarial, registra Lupion (2014) que deve prevalecer a autodeterminação e autorresponsabilidade do contratante, exigindo-se um esforço adicional do empresário, posto que ele poderia ter evitado os seus efeitos e prejuízos deixando de contratar.

Atrelado ao risco está o erro. 0 empresário pode se equivocar em suas previsões e jogadas e, com isso, obter um resultado completamente diverso do originalmente esperado, tendo de arcar com o prejuízo. Diferentemente do contexto não empresarial, onde se pune o prejuízo e valoriza-se o lucro, no âmbito empresarial ambos são faces da mesma moeda (DEZEM; OLIVEIRA FILHO, 2019).

Destaca-se, com isso, outro norte interpretativo, que é contrato e erro - jogada equivocada do agente econômico.

O erro no âmbito empresarial é esperado e, até mesmo, desejado pelo sistema jurídico, haja vista que faz parte da dinâmica de mercado, regulando o sistema concorrencial. As variadas estratégias econômicas adotadas pelos agentes do mercado e os diferentes resultados por elas obtidos, uns melhores outros piores, são os elementos que dão vida a um ambiente de competição. Os empresários buscam invariavelmente o maior sucesso econômico, isto é, a adoção da estratégia mais eficientes (FORGIONI, 2019, p. 151).

Assim sendo, o prejuízo que advém de jogadas erradas do agente econômico não é condenável ao direito, tampouco sinônimo de desequilíbrios e irregularidades que requeiram a intervenção estatal.

Considerando a essência do empresário já dissecada, a jogada errada é inerente ao risco da tomada de decisões e suas consequências negativas não podem, por si só, ensejar tutela estatal no sentido de alterá-las: o direito não tem o condão de corrigir os erros eventualmente praticados pelo empresário e o judiciário deverá interferir minimamente nas relações mercantis (LUPION, 2014).

Ante todo o exposto, vê-se que as relações empresariais devem ser interpretadas invariavelmente à luz da inexorável busca do lucro e que, a partir disso, as partes que compõem o contrato estão cientes de sua função econômica, motivo pelo qual agem egoisticamente, perseguindo seus próprios interesses, avaliando os custos de transação, alocando, dividindo e assumindo riscos, bem como se expondo a jogadas equivocadas.

\section{CONCLUSÃO}

Pelo exposto, é notório que a aplicação da doutrina dos vícios de consentimento deve se moldar à realidade empresarial quando se analisa a possibilidade de sua ocorrência em pactos mercantis.

Quando se considera o dolo e a coação, ambos são produto de má-fé e ferem as cláusulas gerais da boa-fé contratual e função social do contrato, devendo ser coibidos independentemente da natureza do pacto.

No que tange ao erro, contudo, inexiste máfé aparente, haja vista que o vício se operou no íntimo do próprio contratante que externalizou sua vontade, sem que terceiros tenham interferido para tanto. Há que se atentar, dessa forma, para as naturezas do agente e do negócio em si, bem como para a espécie de erro, se em relação à pessoa, ao negócio, à forma etc.

Nessa toada, importante frisar que os pactos empresariais diferem muito dos demais contratos, tendo em vista sua natureza eminentemente mercantil, que busca sempre o lucro. Com isso, os pactos mercantis são sempre envoltos do risco do negócio, podendo alcançar o objeto esperado ou não, resultando em prejuízos.

Com isso, ainda que o contrato tenha acarretado revés a uma das partes, não é necessariamente eivado de irregularidade. Em verdade, pode ser apenas o produto de uma escolha equivocada do empresário que avaliou mal os seus parceiros econômicos, conteúdo do pacto, forma do instrumento, riscos envolvidos etc.

Além do mais, presume-se que os empresários que compõem o contrato estão cientes de tais riscos e os diluem e dividem entre eles, alocando-os de tal forma que satisfaça aos anseios comerciais de ambos. O erro enquanto vício de vontade, portanto, deve ser encarado nesse contexto, ou seja, como uma possibilidade intrínseca à natureza do contrato empresarial. 
Tendo em vista que nenhum empresário age senão em busca da vantagem econômica e que, ao agir, presume-se que considerou todos os fatores que envolvem o negócio, entende-se que seu erro Ihe parecia lucrativo e, por isso, o contrato empresarial atingiu sua finalidade, isto é, buscou o lucro.

Ademais, os agentes empresários em hipótese alguma se enquadram no padrão do homem médio. Ao contrário, são sujeitos técnicos, que dominam não só os pormenores de sua atividade, mas também do funcionamento do mercado e da ciência da administração e, por isso, todas as decisões à frente da empresa são, presumese, as mais adequadas à realidade da empresa, em consonância com um planejamento prévio.

Dessa forma, o empresário, em uma relação contratual empresarial, não comete erro escusável, justamente porque qualquer equívoco nesse contexto não lhe é desculpável, mas sim fruto de falta de preparo, avaliação ou diligência.

Diferentemente dos demais vícios de consentimento, quais sejam, o dolo e a coação, o erro não é aplicável aos contratos empresariais, sob pena de ser o pacto mercantil completamente descaracterizado em sua essência.

\section{REFERÊNCIAS}

AGUIAR JÚNIOR. Ruy R. de. Contratos relacionais, existenciais e de lucro. Revista Trimestral de Direito Civil, Rio de Janeiro, v. 45, n. 12, p. 91-110, jan./mar. 2011.

AMARAL, Francisco. Direito Civil: introdução. 10. ed. São Paulo: Saraiva, 2018.

AZEVEDO, Antônio J. Negócio Jurídico: existência, validade e eficácia. 4. ed. São Paulo: Saraiva, 2002.

BRASIL. Presidência da República. Lei n. 10.406 de 10 de jan. de 2002. Institui o Código Civil. Diário Oficial da União, Brasília-DF, 11 de janeiro de 2002. Disponível em: http://www.planalto.gov.br/ccivil_03/leis/2002/L10 406.htm. Acesso em: 01 de jul. 2020.

BRASIL. Presidência da República. Lei Lei n. 6.404 de 15 de dez. de 1976, Dispõe sobre as Sociedades por Ações. Diário Oficial da União, Brasília-DF, 17 de dezembro de 1976. Disponível em: http://www.planalto.gov.br/ccivil_03/leis/16404cons ol.htm. Acesso em: 01 de julho de 2020.
BULGARELLI, Waldírio. Tratado de direito empresarial. 4. ed. São Paulo: Atlas, 2000.

CABRAL, Érico de P. A "autonomia" no direito privado. Revista de Direito Privado, São Paulo, v. 19, p. 83-129, jul. 2004.

CARNEIRO FILHO, Humberto J.; VIANA, Raphael F. B. Breve ensaio sobre a autonomia dos contratos interempresariais. Revista de Direito Privado, São Paulo, v. 63, p. 103-124, jun./set. 2015.

CARVALHOSA, Modesto. Comentários à Lei de sociedades anônimas. 6. ed. São Paulo: Saraiva, 2013. v.3.

CHIAVENATO, Idalberto. Introdução à teoria geral da administração: uma visão abrangente da moderna administração das organizações. 10 ed. São Paulo: Atlas, 2020.

COELHO, Fabio Ulhoa. Curso de Direito Comercial: direito de empresa. 18. ed. São Paulo: Saraiva, 2014. v. I.

DEZEM, Renata M. M. M.; OLIVEIRA FILHO, Paulo F. de. Os reflexos da interpretação dos contratos empresariais pelo poder judiciário. Cadernos Jurídicos da Escola Paulista da Magistratura, São Paulo, n. 50, v. 20, p. 123-141, jul./ago. 2019.

DINIZ, Maria Helena. Código Civil Anotado. 16. ed. São Paulo: Saraiva, 2012.

FORGIONI, Paula A. Contratos Empresariais: teoria geral e aplicação. 4. ed. São Paulo: Thomson Reuters Brasil, 2019.

GALESKI JUNIOR, Irineu; RIBEIRO, Marcia C. P. Teoria geral dos contratos: contratos empresariais e análise econômica. 2. ed. São Paulo: Revista dos tribunais, 2015.

GOMES, Orlando. Introdução ao Direito Civil. 22. ed. Rio de Janeiro: Forense, 2019a.

GOMES, Orlando. Contratos. 27. ed. Rio de Janeiro: Forense, 2019b.

HENTZ, Luis A. S.; SABONGI, Camila M. Business judgment rule no direito societário brasileiro. Revista do Direito Bancário e do Mercado de Capitais, São Paulo, vol. 73, p. 02-23, set. 2016. 
KONDER, Carlos N.; TEPEDINO, Gustavo. Fundamentos do Direito Civil: contratos. 1. ed. Rio de Janeiro: Forense, 2020.

LUPION, Ricardo. Interpretação dos Contratos Empresariais - sem fobia e sem idolatria. Revista da AJURIS, v. 41, n. 135, p. 405-423, set. 2014.

MALUF, Carlos A. D. Introdução ao Direito Civil. 2. ed. São Paulo: Saraiva, 2018.

MIRANDA, Custódio da P. U. Teoria Geral do Negócio Jurídico. 2. ed. São Paulo: Atlas, 2009.
PEREIRA, Caio M. da S. Instituições de Direito Civil: introdução ao direito civil: teoria geral de direito civil. 33. ed. Rio de Janeiro: Forense, 2020a. v. 1. PEREIRA, Caio M. da S. Instituições de Direito Civil: contratos 24. ed. Rio de Janeiro: Forense, 2020b. v. 3.

RIBEIRO, Marcia C. P. Contratos empresariais. Enciclopédia Jurídica da PUCSP. Tomo Direito Comercial. 1. ed., julho de 2018, disponível em: https://enciclopediajuridica.pucsp.br/verbete/252/e dicao-1/contratos-empresariais.

TOMAZETTE, Marlon. Curso de direito empresarial: teoria geral e direito societário. 11. ed. São Paulo: Saraiva, 2019. v. 1. 